\title{
Rediscover traditional gypsum: Territory, traditional architecture and rediscovery of traditional gypsum
}

\author{
Belén González-Sánchez ${ }^{1}$, Antonia Navarro Ezquerra ${ }^{1}$, Manuel Julià Comas ${ }^{2}$, \\ Judit Ramirez-Casas ${ }^{1}$ and Mariana Palumbo Fernandez ${ }^{1}$ \\ ${ }^{1}$ Department of Architectal Technology, Universitat Politècnica de Catalunya \\ Av. Doctor Marañon 44-50, 08028 Barcelona (Spain) \\ antonia.navarro@upc.edu \\ ${ }^{2}$ Architect and archaeologists, Center for the study of gypsum (CEG) \\ Carrer Major, 23, 08750 Molins de Rei (Spain)
}

\begin{abstract}
In the region of La Segarra, in the province of Lleida (Spain), there is a geological formation of the Oligocene age, called the "Talavera Gypsum Formation". The traditional buildings located in this area are built with this material, and its use ranges from ornamental elements to complex and structural construction systems. Within the traditional patrimony of the area, we can find in a generalized way the use of gypsum in defensive towers, churches, castles and private houses, among other patrimonial elements of the territory. In this article, some representative buildings of the area are analysed, indicating their geographical and geological location. Moreover, with the aim of obtaining a material suitable for future restoration of La Segarra region's built heritage, and by extension, of all the heritage built using this material, a traditional gypsum furnace was built, the firing temperatures within the furnace were monitored during the firing process, and the product obtained was characterized by mineralogical.
\end{abstract}

Keywords: Traditional architecture, gypsum, construction systems, materials, territory, built heritage.

\section{Introduction}

As architectural constructions have progressed, increasing in simultaneously and reducing the thickness of their walls, building materials have also changed. In fact, there is still a debate about if architecture has conditioned the search for new building materials, or if the finding of these has contributed to the evolution of architecture.

Up to the 20th century, the construction use of materials and the architectural techniques was linked to the resources available in the near territory, which explains why, in the built heritage, the same material is used in a wide diversity of construction systems (La Spina, 2016). 
Among the binding materials used in traditional construction, lime is the best known. However, another binder with visual characteristics similar to lime; gypsum, is frequently found in such constructions too. This binding materials currently limited to indoor use, in linings and plasterboard, and can be acquired in the market within a variability of products limited by the existing regulations (AENOR, 2010; AENOR, 2012; AENOR, 2009).

Nonetheless, traditionally, and especially in geological gypsum areas, gypsum has been used in a wider range of applications, either in floors, ceilings, beams, walls, partitions, and even in external coatings. The versatility of this material depends essentially on its purity and the firing temperature (Navarro and Julià, 2019; La Spina and Grau, 2020).

In the region of La Segarra, in the province of Lleida (Spain), there is a geological formation of the Oligocene age, called the "Talavera Gypsum Formation" (Pla et al., 2016). The traditional buildings located in this area are built with this material, and its use ranges from ornamental elements to complex and structural construction systems. Within the traditional patrimony of the area, we can find in a generalized way the use of gypsum in defensive towers, churches, castles and private houses, among other patrimonial elements of the territory (Garganté, 2006; Llobet, 2012; Martí, 2018).

In this article, some representative buildings of the area are analyzed. Moreover, with the aim of obtaining a material suitable for future restoration of La Segarra region's built heritage, and by extension, of all the heritage built using this material, a traditional gypsum furnace was built, when the firing temperatures within the furnace were monitored during the firing process, and the product obtained was characterized.

\section{Arquitectura de la Segarra}

According to the documents kept in the Arxiu Comarcal de la Segarra (Cervera), in 1486, plaster made by the farmers of Sant Pere dels Arquells i Vergós de la Ribera (two villages in La Segarra) was supplied for the construction of the church of Santa Maria de Cervera, and years later for various private constructions. It seems that in the 16th century there was a strong demand for gypsum in the area, which led to an increase in the price of plaster, until in the 17th century a selling price was set by the local authorities. Some historical studies explain that in the 19th century the use of lime and gypsum was very abundant in the towns of La Segarra (Garganté, 2006).

This use of plaster can be clearly documented in the different constructions that are spread throughout the area today. We find examples in both private and public architecture, and in various municipalities such as those described in the study carried out by the architect Antoni Martí in Torà, Biosca, Cervera or Talavera, among others (Martí, 2018).

Although gypsum is conceived as a building material from the firing and grinding of gypsum stone, there are also examples of the use of gypsum stone in its natural state for the construction of cyclopean walls, such as those found at Timor Castle (in the 
municipality of Sant Pere dels Arquells). This construction is documented from the 12th century onwards (Pladevall, 1997), and a farmhouse was built on top of it in the 17th or 18th century, which was inhabited until the second half of the 20th century (Fig. 1). Nowadays it is in ruins, as well as the nearby church of Sant Jaume de Timor where there are also many constructive elements made of plaster in its natural state and as a building material.

Just walking through the aforementioned Segarra villages, one can see the extensive use of plaster in construction in general. Thus, plaster as an exterior rendering gives buildings that still remain a particular characteristic, both in terms of shape and appearance, and gives them a roughness that is difficult to achieve with other materials.
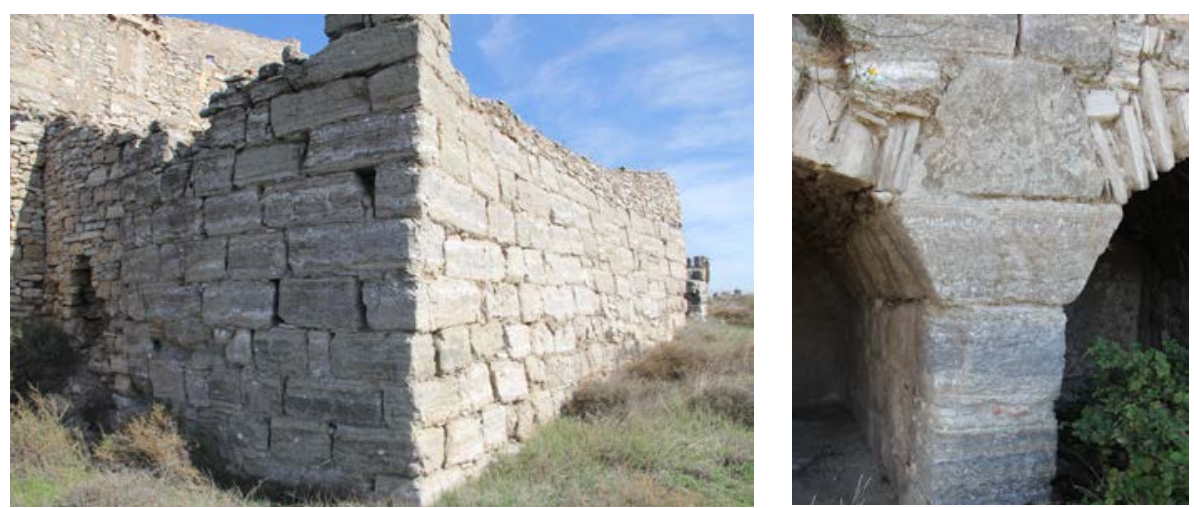

Fig. 1 Cyclopean plaster wall (left) and plaster stone pillar supporting two plaster stone arches taken with plaster mortar (right), Timor Castle

There are many examples in the construction of the walls, ranging from masonry with gypsum mortar as a bonding agent, to walls made of rammed earth with gypsum concrete, to thin walls made of mass plaster or those with stone slabs inside.

The masonry walls were usually covered with plaster, although few remains today, especially in the door jambs, edges of doors and windows. These were made of a thinner and harder plaster, which also served as a master to facilitate the execution of the plastering. The existence of these edges allows us to see the evolution of the façades, since in certain cases we can see, for example, how what was once a door later became a window, and the conservation of the profiles of the openings.

On the façades of the houses, there are also cornices and cantilevers made of plaster that finish off the upper part of the walls, and door decorations made of plaster are also documented.

We find interesting examples of covered passages in the streets of La Segarra made in the form of a vault or with wooden beam slabs and interlaced with plaster vaults. An example of a flat plaster ceiling with molded decoration can be found in a covered walkway in Torà. This is a fairly widespread technique in Catalonia and has a varied iconography that is repeated in different areas. 
The use of plaster on the joists allows for the creation of the upper part of the floors, which are also mostly plaster-based, but with different characteristics to those of the vault itself (Fig. 2).

In Cervera and Talavera there are examples of basements with barrel vaults made of mass-produced gypsum concrete or with brickwork and also with groin vaults and fajon arches (Fig. 3).

Perhaps one of the most representative examples of the use of plaster in architecture from a structural point of view is the tower of Ivorra. With a circular floor plan and a height of about 20 metres, it is dated to around the year one thousand (Martí, 2018). After carrying out some complete previous studies, it has been concluded that this tower is built with mass-produced plaster, and for this reason in the restoration carried out in 2013 and 2014 the original aspect was recovered with the application of plaster in the deteriorated and disappeared parts (Fig. 4).

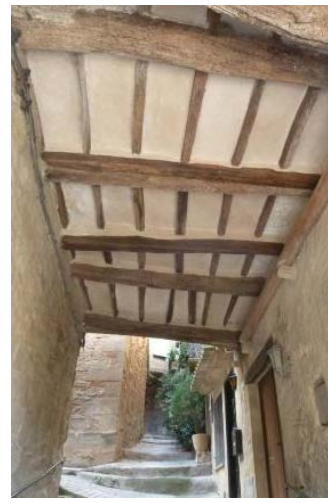

Fig. 2 Flat roof in covered passage, Torà

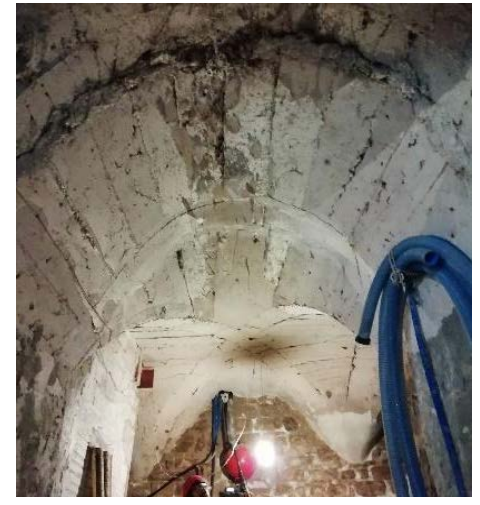

Fig. 3 Basement with barrel vault, Talavera

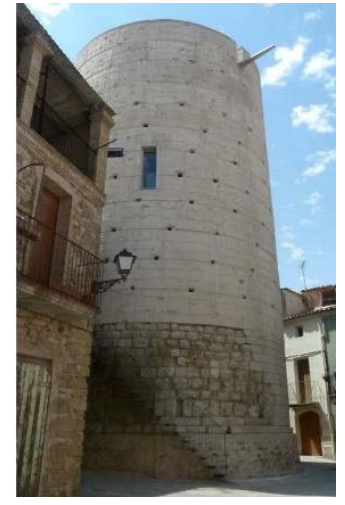

Fig. 4 Outside Ivorra tower

\section{The geology of the Segarra}

Geologically, the Segarra region is located in a land of geological formation from the Oligocene period, dated between 40 and 25 million years B.C., where the formation known as the "Talavera Gypsum" emerges, interspersed with large layers of marl (Pla et al., 2016).

According to the information available at the "Institut Cartogràfic i Geològic de Catalunya" (ICGC), the towns of Cervera, Vergós, Sant Pere dels Arquells, Timor, Sant Antolí i Vilanova, and Talavera, are located on land composed of alternating gypsum and marl, known as the "Talavera Gypsum" (POxm) formation. The towns of Biosca and Ivorra are located close to soils composed of gray marl and sandstone with intercalation of gypsum (PEox). Finally, the town of Torà is located in nearby land composed of gypsum and marl, known as the "Balbastre gypsum" formation (Fig. 5). 
Currently, the company Cemento Natural Tigre, located in the town of Cervera, exploits large layers of marl to produce NHL hydraulic limes and natural cements. However, in the quarries where it exploits its raw material there are outcrops of gypsum, interspersed between the marls, which are not productive and are stockpiled to later fill in the finished quarry fronts. The composition of these gypsums varies in terms of their degree of purity and associated minerals (calcite, dolomite, clays, quartz).
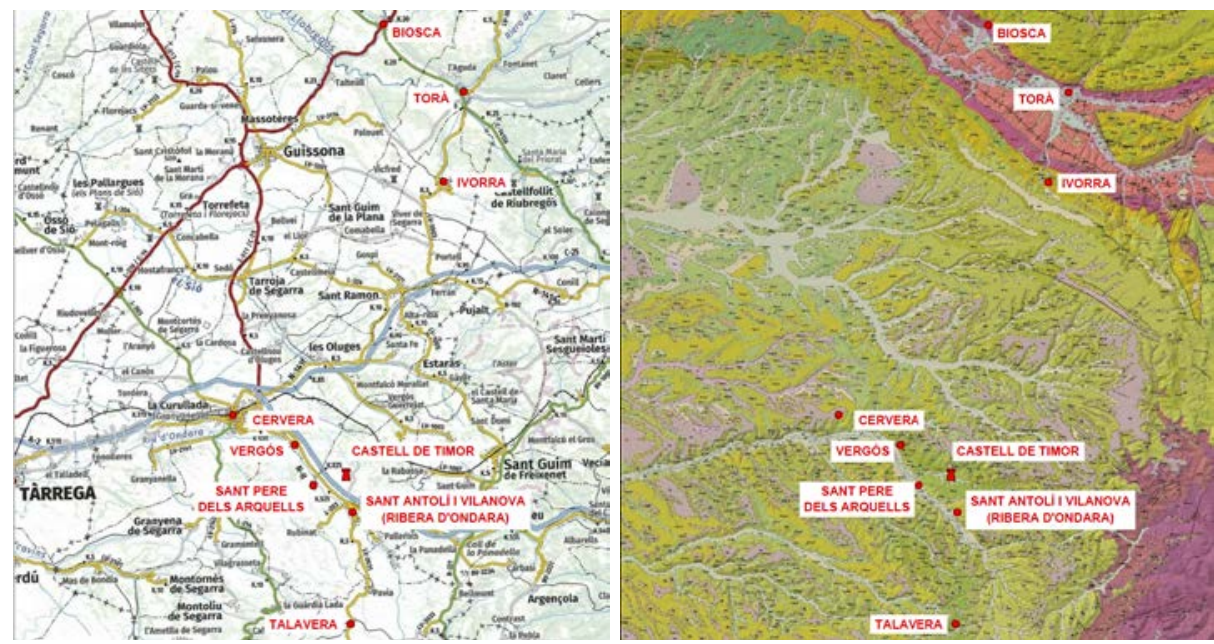

Fig. 5 Topographical map (left) and geological map (right) of the Segarra area with indications of the towns studied

\section{Recovery of a traditional gypsum oven}

At the end of November 2018 the congress "El guix tradicional en el patrimoni construit" organized by the Centre d'Estudis del Guix (CEG), took place in Ribera d'Ondara, located to the east of the city of Cervera. This meeting brought together professionals, academics, students and amateurs, to share knowledge and recover popular wisdom regarding the construction of a traditional gypsum oven.

The morphology of the kiln built was characterized by a square floor plan, with a cylindrical section, open, uncovered, medium-sized, half-buried, isolated, built on one side of the quarry front of Cemento Natural Tigre, finished off on three of its four sides with a brickwork with exposed ceramic bricks, and with two entrances that formed a false vault (La Spina and Grau, 2020).

The oven was lighted with pine wood due to the difficulties in obtaining other combustible material that was sufficient for the correct development of the cooking of the gypsum, although traditionally native vegetation was used. In the last phase of 
burning the oven, gypsum vegetation from the area was used. The oven was shut down by sealing the two entrances (CEG, 2020a; CEG, 2020b; CEG, 2020c).

The particularity of this traditional plaster oven was the incorporation of temperature sensors in different areas in order to monitor its thermal evolution during the plaster firing process, and the comparative study of the samples collected.

\section{Materials and methodology}

\subsection{Mineralogical composition}

Before the experimental development of the traditional gypsum furnace, two samples of gypsum stone were collected from the Cemento Natural Tigre quarry. The selection criterion of these samples was their visual heterogeneity. Once the oven was fired, the resulting material was homogenized and samples were also collected.

These two groups of samples were analysed in the laboratory to determine their mineralogical composition by X-ray diffraction (XDR), comparing the results obtained with the data already analysed in previous laboratory work on gypsum mortars in the Ivorra Tower and the Timor Castle.

The diffractometer used is a PANalytical X'Pert PRO MPD Alphal power diffractometer in Bragg-Brentano $\theta / 2 \theta$ geometry of 240 millimetres of radius, nickel filtered $\mathrm{Cu} \mathrm{K} \alpha$ radiation and sample spinning at 2 revolutions per second.

\subsection{Evolution of the temperature of the traditional plaster oven}

The traditional gypsum oven was monitored, at 21 different points distributed homogeneously over the entire surface of the interior structure of the oven made with the gypsum stone itself, with type K high-temperature sensors $\left(1400^{\circ} \mathrm{C}\right)$. Readings were taken with the Applent AT4532 multi-channel temperature meter, which was connected to a battery, powered by a $150 \mathrm{~W}$ Poly-crystalline silicon siries solar panel with an energy transformer (DC $12 \mathrm{~V}$ to AC 220V) during the entire plaster firing process, from the time the oven was switched on to the time it was switched off and the resulting material was cooled (48 hours in total).

\section{Results}

\subsection{Characterization of the gypsum}

The study of the two gypsum stone samples collected before the experimental development of the traditional gypsum oven [Gypsum Stone "A" and Gypsum Sone "B”], reflect that in both cases the presence of hydrated gypsum was detected, although 
in a very variable proportion, ranging from $40 \%$ to $95 \%$. The soil studied is rich in calcite and dolomite, which is found in both samples with variable concentrations, and the most predominant clay in the area is Muscovite.

Analysis of samples of traditional gypsum [Traditional gypsum] indicates that in addition to anhydrous gypsum (77\%), hemihydrate (9\%) and dihydrate (2\%), phases of calcium silicates, which are characteristic of hydraulic limes, have also been detected in a proportion of $10 \%$.

The mineralogical composition of some samples taken from the tower of Ivorra and the castle of Timor was also studied [Ivorra tower gypsum and Timor castle gypsum respectively]. These samples indicate that the gypsum is fully hydrated, although the presence of non-reactive anhydrite gypsum has also been detected in Timor Castle. The presence of carbonate phases (calcite) and hydrated hydraulic phases (hydrated bicalcium silicate) was also detected.

Table 1 Semi-quantitative (\%) X-ray diffraction (XRD) analyses of the samples analysed

\begin{tabular}{lcccccccccc}
\hline Sample & $\mathrm{G}_{\mathrm{D}}$ & $\mathrm{G}_{\mathrm{H}}$ & $\mathrm{G}_{\mathrm{A}}$ & $\mathrm{Qz}$ & $\mathrm{C}$ & $\mathrm{D}$ & $\mathrm{M}$ & $\mathrm{A}$ & $\mathrm{C}_{2} \mathrm{~S}$ & $\mathrm{SCH}$ \\
\hline Gypsum stone “A” & 95 & - & - & 2 & 3 & - & - & - & - & - \\
Gypsum stone “B” & 40 & - & - & 6 & 28 & 6 & 17 & 3 & - & - \\
Traditional gypsum & 2 & 9 & 77 & - & 2 & - & - & - & 10 & - \\
Ivorra tower gypsum & 51 & - & - & 8 & 32 & - & - & - & - & 9 \\
Timor castle gypsum & 85 & - & 9 & - & 4 & - & - & - & - & 2 \\
\hline
\end{tabular}

$\mathrm{G}_{\mathrm{D}}=$ calcium sulphate dihydrate; $\mathrm{G}_{\mathrm{H}}=$ calcium sulphate hemihydrate; $\mathrm{G}_{\mathrm{A}}=$ anhydrite;

$\mathrm{Qz}=$ quartz; $\mathrm{C}=$ calcite; $\mathrm{D}$ = dolomite; $\mathrm{A}=$ Analcime; $\mathrm{C}_{2} \mathrm{~S}=$ Belite; $\mathrm{SCH}=$ Tobermorite

\subsection{Thermal analysis of the traditional gypsum oven}

Based on the thermal data collected in situ, this study has only analysed 10 reading points, located according to figures 6 and 7, corresponding to the data of the false left vault. The graphic representation is highlighted in colours according to its spatial location, where the lilac colours represent the lower part of the furnace, the blue ones the lower-middle part, the green ones the central area and the red ones the upper area.
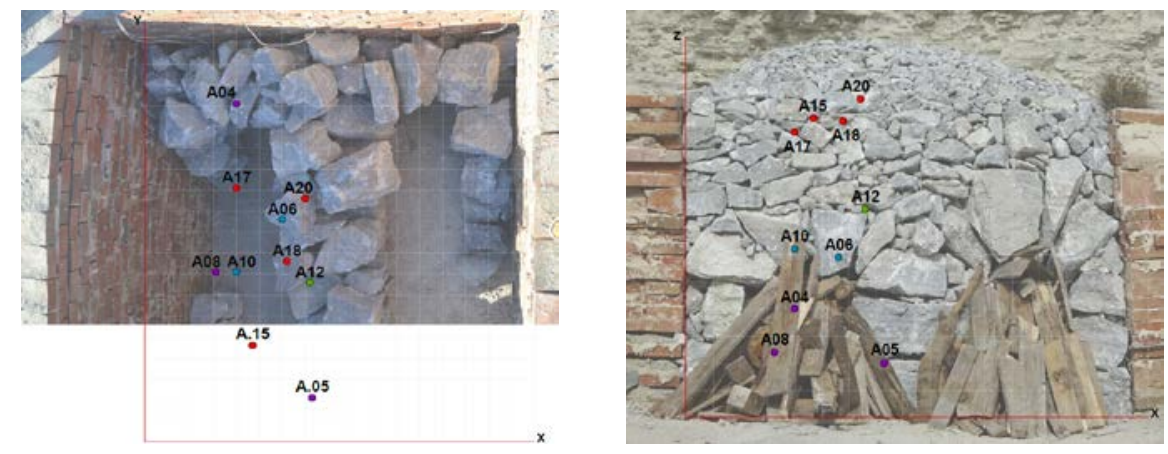
Fig. 6 Plant of the traditional gypsum oven

Fig. 7 Elevation of the traditional gypsum oven

In the following graph (Fig. 8) we can see that the temperatures with the greatest oscillation correspond to the lower zone of the kiln (lilac colour), due to its proximity to the flames produced by the burning of the fuel, in this case pine wood, by the incorporation of new material that rapidly decreases its temperature, and by the production of embers at the base of the kiln. The highest average temperatures reached in this area would be around $700^{\circ} \mathrm{C}$, with peaks of over $800^{\circ} \mathrm{C}$.

The highest temperatures are obtained in the lower-middle zone of the oven (blue colour) with punctual temperature peaks above $1000^{\circ} \mathrm{C}$, and with an average thermal accumulation of between $600^{\circ} \mathrm{C}$ and $900^{\circ} \mathrm{C}$ for more than 150 minutes.

The temperatures with less oscillation and with some curves, of ascent and descent, more moderate are in the superior zone of the furnace (red colour). The average temperature of the area during the furnace burning process is between $300^{\circ} \mathrm{C}$ and $400^{\circ} \mathrm{C}$, with two specific maximum peaks of $650^{\circ} \mathrm{C}$ and $750^{\circ} \mathrm{C}$ respectively.

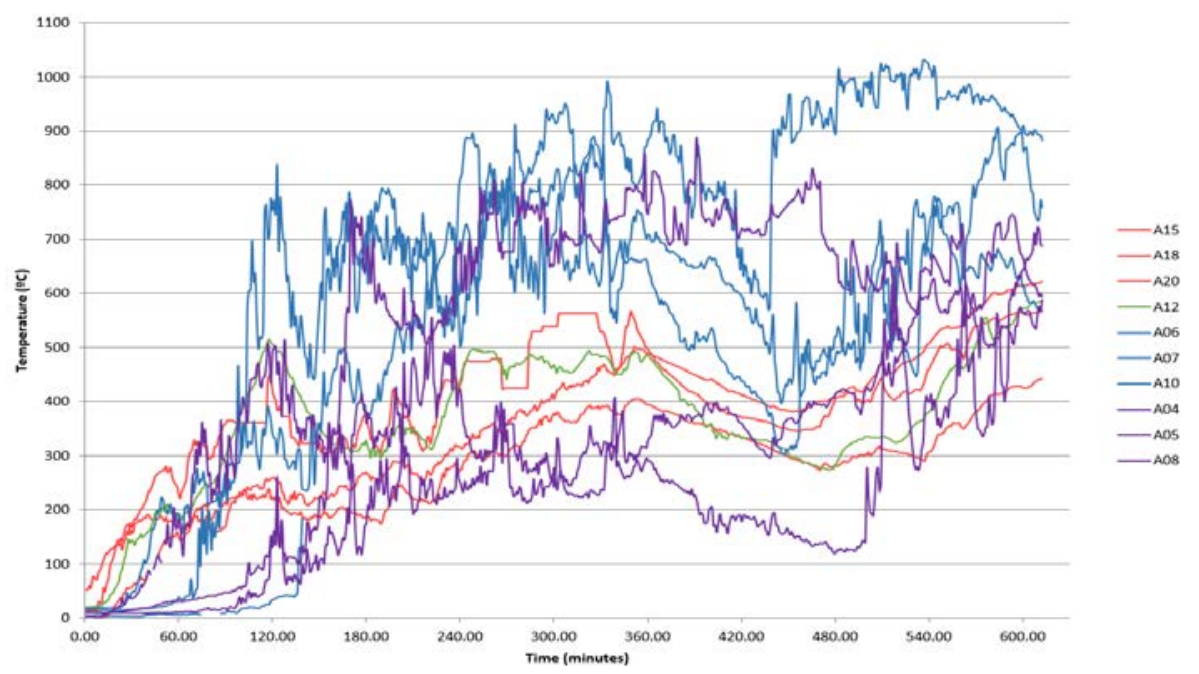

Fig. 8 Graph of the thermal evolution of traditional gypsum oven firing

The central zone of the oven (green colour), despite what might initially be expected from the thermal behaviour of this zone, has a very similar evolution to the data collected in the upper zone of the oven. This phenomenon could be produced by the generation of internal current which generates a loss of heat from the central zone of the oven.

The Table 2 shows the firing temperature values of the traditional plaster oven according to the literature consulted (Ruiz, 1973; Sanz, 2009; Bel-Anzué, 2017), with the different compounds found in the mineralogical analysis of the samples analysed by X-ray diffraction.

As can be seen, the highest percentage (77\%) corresponds to anhydrite, which requires a temperature between $300^{\circ} \mathrm{C}$ and $700^{\circ} \mathrm{C}$ for its transformation. If we analyse 
the temperature graph, only the gypsum located in the lower-middle zone of the oven has acquired these temperatures.

Both the calcium sulphate dehydrate (2\%) and the calcite (2\%) resulting from the mineralogical analysis correspond to unfired material, in other words, the firing in the gypsum furnace is very heterogeneous and the innermost zone of some gypsum stones has not received any heat. This is also the explanation for the appearance of calcium sulphate hemihydrate (9\%), which requires a temperature of between $100^{\circ} \mathrm{C}$ and $170^{\circ} \mathrm{C}$ for its transformation.

The calcium silicate $(10 \%)$ detected in the mineralogical analysis needs temperatures above $850^{\circ} \mathrm{C}$, and is formed by the combination of calcium oxide and silicon oxide, coming from the decomposition of the limestone and clays present in the quarry face studied. The appearance of this compound generates what is known as "hydraulic gypsum", and gives better performance to the final product.

Table 2 Relationship between processing temperature and generated compounds

\begin{tabular}{|c|c|c|c|c|}
\hline & Name & Mineral phase & Temp. & $\mathrm{XDR}$ \\
\hline \multirow{6}{*}{ G } & Calcium sulphate dihydrate & $\mathrm{CaSO}_{4}+2 \mathrm{H}_{2} \mathrm{O}$ & Ambient & $2 \%$ \\
\hline & Calcium sulphate hemihydrate & $\mathrm{CaSO}_{4}+0.5 \mathrm{H}_{2} \mathrm{O}+\uparrow 1.5 \mathrm{H}_{2} \mathrm{O}$ & $100-170^{\circ} \mathrm{C}$ & $9 \%$ \\
\hline & Anhydrite III & $\mathrm{CaSO}_{4}$ & $170-300^{\circ} \mathrm{C}$ & \\
\hline & Anhydrite II & $\mathrm{CaSO}_{4}$ & $300-700^{\circ} \mathrm{C}$ & $77 \%$ \\
\hline & Anhydrite I & $\mathrm{CaSO}_{4}$ & $+1200^{\circ} \mathrm{C}$ & \\
\hline & Calcium oxide & $\mathrm{CaO}+\uparrow \mathrm{SO}_{3}$ & $+800^{\circ} \mathrm{C}$ & \\
\hline \multirow{4}{*}{$\mathrm{C}$} & Clay & $\mathrm{mSiO}_{2} \cdot \mathrm{nAl}_{2} \mathrm{O}_{3} \cdot \mathrm{pFe}_{2} \mathrm{O}_{3} \cdot \mathrm{qH}_{2} \mathrm{O}$ & Ambient & \\
\hline & Alumina & $\mathrm{Al}_{2} \mathrm{O}_{3}+\uparrow 2 \mathrm{H}_{2} \mathrm{O}$ & $+600^{\circ} \mathrm{C}$ & \\
\hline & Silica & $\mathrm{SiO}_{2}+\uparrow 2 \mathrm{H}_{2} \mathrm{O}$ & $+600^{\circ} \mathrm{C}$ & \\
\hline & Iron oxide & $\mathrm{Fe}_{2} \mathrm{O}_{3}+\uparrow 2 \mathrm{H}_{2} \mathrm{O}$ & $+600^{\circ} \mathrm{C}$ & \\
\hline \multirow{2}{*}{$\mathrm{L}$} & Calcite & $\mathrm{CaCO}_{3}$ & Ambient & $2 \%$ \\
\hline & Calcium oxide & $\mathrm{CaO}+\uparrow \mathrm{CO}_{2}$ & $+850^{\circ} \mathrm{C}$ & \\
\hline $\mathrm{X}$ & Calcium silicate & $2 \mathrm{CaO} \cdot \mathrm{SiO}_{2}$ & $+850^{\circ} \mathrm{C}$ & $2 \%$ \\
\hline
\end{tabular}

$\mathrm{G}$ = gypsum; $\mathrm{C}=$ clay; $\mathrm{L}=$ limestone; $\mathrm{X}$ = combination mineral phase

\section{Conclusions}

In this study it has been possible to demonstrate that in the manufacture of traditional gypsum a mono-mineral stone is not used, but that gypsum is associated with other minerals such as clays, limestone, quartz, etc. As we have seen in the temperature graph, when a heterogeneous firing of the material takes place in a traditional gypsum kiln, with maximum temperature peaks above $1000^{\circ} \mathrm{C}$, the associated minerals are also transformed into new compounds that combine with each other, such as belite (bicalcium silicate), obtaining the formation of hydraulic phases. When this happens, it is popularly said that we have "hydraulic gypsum". 
The study of the existing gypsums in the constructions of the tower of Ivorra and the castle of Timor, reflects that these have similar compositions to those obtained in the baked stone of our traditional gypsum furnace, which does not happen with the industrial gypsums used in the construction sector. That is why we propose the use of a traditionally baked plaster to rehabilitate this type of building, to guarantee the compatibility of materials and the durability of the applied material.

\section{Acknowledgements}

The authors of this study would like to thank the Centre d'Estudis del Guix for organizing the congress "El guix tradicional en el patrimoni construït", as well as all the participants who took part in the course; the company Cemento Natural Tigre for providing its facilities, machinery and raw materials to build the traditional gypsum oven; Professor Felipe Buill for his active participation in the documentation process of the experimental part; the EPSEB-UPC for financing part of the experimental monitoring material. Finally, we would like to thank the UPC for awarding the FPI-UPC 2018 grant to hire research staff in training to carry out the doctoral thesis.

\section{References}

La Spina, V. (2016). Estudio del yeso tradicional en España. Yacimientos, canteras, hornos y la arquitectura tradicional, su estado de conservación y propuestas de itinerarios visitables para su revalorización y difusión (Informe). Madrid: Instituto del Patrimonio Cultural de España, Ministerio de Educación, Cultura y Deporte.

Asociación Española de Normalización y Certificación. UNE-EN 520:2005+A1: Placas de yeso laminado. Definiciones, especificaciones y métodos de ensayo. Madrid: AENOR, Feb. 2010.

Asociación Española de Normalización y Certificación. UNE-EN 12859: Paneles de yeso. Definiciones, especificaciones y métodos de ensayo. Madrid: AENOR, Apr. 2012.

Asociación Española de Normalización y Certificación. UNE-EN 13279-1: Yesos de construcción y conglomerantes a base de yeso para la construcción. Parte 1: Definiciones y especificaciones. Madrid: AENOR, July 2009.

Navarro Ezquerra, A.; Julià, M. (2019). El guix tradicional. L'Informatiu del Col-legi d'Aparelladors i Arquitectes de Barcelona, vol. 360, p. 80-83.

La Spina, V.; Grau Giménez, C.J. (2020). La diversidad tipológica de los hornos tradicionales de calcinación de yeso en España. Informes de la Construcción, vol. 72, 557, e334.

Pla, O.; Ferrer García, J. O.; Gratacós Torrà, Ò.; Muñoz, J. A.; Roca i Abella, E. (2016). Influencia de los niveles evaporíticos sin-orogénicos en la geometría del frente surpirenaico central: Anticlinales de Sanaüja y de La Sentiu-Almenara.Geo-Temas, vol. 16, 1, p. 65-68.

Garganté Llanes, M. (2006). Arquitectura religiosa del segle XVIII a la Segarra i l’Urgell. Condicionants, artífexs i pràctica constructiva. Barcelona: Pagès editors, S.L. 
Llobet i Portella, J.M. (2012). Els materials de construcció a Cervera al llarg dels temps i la seva procedència. Els materials de l'arquitectura popular, 10. p. 116.

Martí Falip, A. (2018). El guix en la construcció tradicional de la Segarra. El guix tradicional en el patrimoni construït, Ribera d’Ondara Oct. 25-27.

Pladevall i Font, A. (1997). Catalunya Romànica. Segrià, les Garrigues, el Pla la Segarra, l’Urgell. Barcelona: Enciclopèdia Catalana, vol. 24.

Centre d'Estudis del Guix (2020a). Time-lapse del proceso de carga del horno de yeso tradicional construido durante las II Jornadas de Yeso Tradicional en Ribera d'Ondara [on line]. Barcelona: UPC, 2020 [Retrieved: 10 Desember 2020]. Available to: https://youtu.be/uEA4jZIPMY4

Centre d'Estudis del Guix (2020b). Time-lapse del encendido y quema del horno de yeso tradicional construido durante las II Jornadas de Yeso Tradicional en Ribera d'Ondara [on line]. Barcelona: UPC, 2020 [Retrieved: 10 Desember 2020]. Available to: https://youtu.be/Evevzz-_5r4

Centre d'Estudis del Guix (2020c). Time-lapse de la descarga del horno de yeso tradicional construido durante las II Jornadas de Yeso Tradicional en Ribera d'Ondara [on line]. Barcelona: UPC, 2020 [Retrieved: 10 Desember 2020]. Available to: https://youtu.be/XlvDmcbL4qY

Ruiz de Gauna, A. (1973). La determinación del contenido en yeso hemihidrato y dihidrato en los Cementos por anàlisis térmico. Materiales de construcción, vol. 23, 152, p. 5-25.

Sanz Arauz, D. (2009). Análisis del yeso empleado en revestimientos exteriores mediante técnicas geológicas (doctoral thesis). Universidad Politécnica de Madrid.

Bel-Anzué, P.; Almagro, A.; Sáez Pérez, M.P.; Rodríguez-Navarro, C. (2017) Influence of the calcination process in traditional gypsum with structural behavior. Ge-conservación 11, 7985. 